\title{
EFFECTS OF TRAMPLING ON A TERRESTRIAL ORCHID ENVIRONMENT
}

\author{
Marilyn H.S. Light ${ }^{1,2} \&$ Michael MacConaill ${ }^{1}$ \\ ${ }^{1}$ 174, rue Jolicoeur, Gatineau QC J8Z 1C9, Canada \\ ${ }^{2}$ Author for correspondence: mlight@uottawa.ca
}

KEY WoRDS: Cypripedium, soil compaction, nematodes, nutrient supply

Orchids and soil communities that support them may be affected when we monitor or conduct investigative procedures, or through tourism especially during the blooming season, but this has never been investigated or quantified (Light 2004). The immediate and direct effect of human disturbance including crushing of flowering plants and seedlings is obvious: broken stems are unlikely to resume growth and a season's reproductive effort can be lost. Disturbance of cover vegetation may expose orchids to predators including human poachers. Fragile ecosystems such as bogs and fens may show immediate effects of trampling but forests and grasslands are also vulnerable to foot traffic although these effects may be less apparent especially when traffic is light (Monz et al. 2000, Farrior 2005). Malmivaara-Lämäsa and Fritze (2003) reported that the microbial community structure of the humus layer in an urban forest in Finland was affected by a cascade of events beginning with trampling compaction then extending to changes in vegetation and litter quality. A useful quantitative measure of the degree of compaction of mineral soils under forested conditions may be had using a pocket penetrometer which is used to produce a standard indentation (Amacher \& O'Neill 2004) while Plant Root Simulator ${ }^{\mathrm{TM}}$ - probes (PRS ${ }^{\mathrm{TM}}$ probes, Western Ag Innovations Inc., Saskatoon, SK, Canada) have been used to assess all soil nutrient ions simultaneously with minimal disruption to the soil environment (Hangs et al. 2002, Hangs et al. 2004). Changes in soil nematode populations reflect changes in soil microenvironments and so are increasingly used as monitors of soil health because their numbers, taxa and trophic groups may reflect the state of soil ecological processes (Yeates et al. 1993, Neher 2001, Yeates 2003). While nematode numbers may be relatively stable in response to changes in moisture and temperature, their populations are known to respond to land management changes in predictable ways (Yeates 2003). The response to trampling in the vicinity of terrestrial orchids is of interest because it could reflect subtle changes in soil microflora including mycorrhizae which might exert a delayed effect on germination and development of seedlings.

Our long term study of temperate terrestrial orchids has revealed that there can be a lag of two or more years before the effect of natural disturbance or climatic perturbation becomes apparent in terms of plant emergence or flowering (Light et al. 2003, Light \& MacConaill 2005, 2006). Because many terrestrial orchids have extended periods of below-ground existence as protocorms before emergence, it may require decades of observation to uncover key variables impacting orchid population establishment or stability. This is especially true of long-lived perennials such as cypripediums (Light \& MacConaill 2005). We hypothesized that the response of the orchid environment to trampling could include changes in soil compaction, nutrient supply, and the soil nematode community and that these responses could be quantified.

To test these hypotheses, we designed a 30-day experiment where we measured soil temperature, soil moisture, soil nutrient supply, and soil compaction over three 10-day intervals before, during, and after flowering of the shallow-rooted Cypripedium parviflorum Salisb. var. pubescens Willd. (Knight). The experimental site was in undisturbed forest in Gatineau Park, Québec, Canada $\left(45^{\circ} 30^{\prime} \mathrm{N}, 75^{\circ} 45^{\prime}\right.$ W) where the orchids grow in Larose land type Brown Forest soil (Lajoie 1962) developed from glacial till over crystalline limestone (70\% sand: $\mathrm{pH}$ $6.8-7.1$ ) on a $10 \%$ slope facing south (Fig. 1). This 


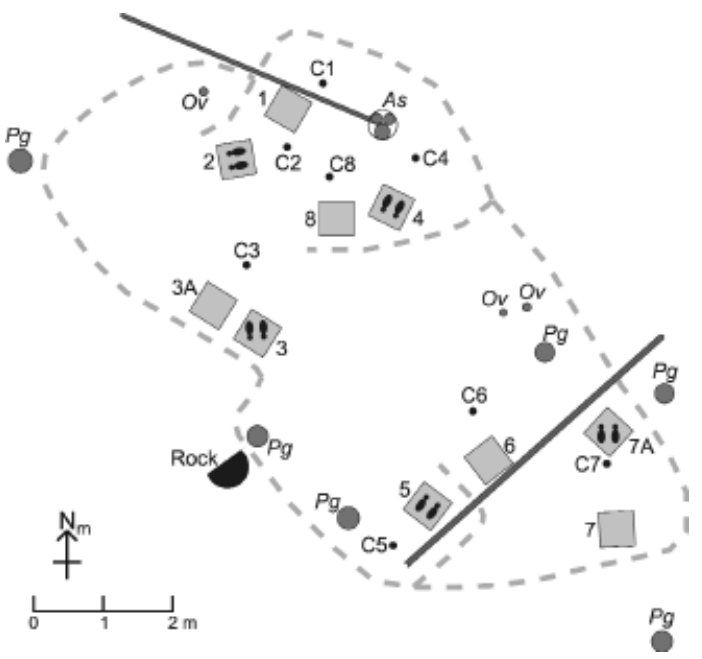

Figure 1. Map of study area. Dark grey circles: significant trees surrounding site (As - Acer saccharum Marsh.; Ov - Ostrya virginiana (Mill.) K. Koch; Pg - Populus grandidentata. Black dots: Test plants of Cypripedium parviflorum var. pubescens $(\mathrm{C} 1-\mathrm{C} 8)$. Light grey squares: $50 \mathrm{~cm}$ square experimental plots (1-8); foot positions when performing a standard visit indicated. Light grey dashed line: Forest trail.

site is dominated by Populus grandidentata Michx. The herbaceous layer consisted primarily of Erythronium americanum Ker., Trillium grandiflorum (Michx.) Salisb., and Eurybia (syn. Aster) macrophylla L. Soil depth where the orchids grow rarely exceeded $10 \mathrm{~cm}$. Paired $50 \mathrm{~cm} \times 50 \mathrm{~cm}$ plots $(5$ pairs: 10 plots) were established approximately $50 \mathrm{~cm}$ from each of eight multi-stemmed orchid plants. Litter composed of fallen tree leaves covered $80-100 \%$ of the plot surfaces. One plot of each pair served as a control and the other was subjected to a daily standard visit during the 10-day blooming period when a $65 \mathrm{~kg}$ person wearing soft-soled shoes performed a 5-minute standing visit ("trampling") at a pre-set position facing an orchid plant. The standard visit emulated what a person might do while observing an orchid: feet were not moved during the visit. Shoe type and visitor weight are reported following the approach suggested by Cole (1995). Control plots were monitored but not disturbed during the experiment except to measure soil temperature and to insert/remove the PRS ${ }^{\mathrm{TM}}$ probes used to assess soil nutrient supply.
Soil moisture during the 30-day experimental period (May 9 - June 8 ) averaged $60 \%$ of dry matter (range: $35-85 ; \mathrm{n}=60$ ). Rainfall over this period was 129.4 $\mathrm{mm}$ on 21 individual days. Soil remained damp to the touch throughout the experiment. Soil temperature ranged from 9.9 to $18.5^{\circ} \mathrm{C}$ (mean: $15.3^{\circ} \mathrm{C}$ over 30 days). Soil compaction (unconfined compressive strength) as measured with a Pocket Penetrometer (Cole-Palmer Model S4651) in the test plots increased steadily over the 10 experimental trampling days (Fig. 2). Footprints became clearly visible beneath covering litter after the first three visits. In the 10-day post-trampling period, there was some recovery from compaction in the test plots, but never to the level of the control plots. We also measured soil compaction along a forest trail that had been created by experimenter traffic adjacent to the plots. We estimate that traffic during the 30 days was equivalent to 50 visitor-passes. This trail showed higher soil compaction than the test plots and this persisted with partial recovery until monthly measurement discontinued at the end of season. Rainfall over the 5-month period (May 9 - Oct 8 ) was $557 \mathrm{~mm}$ on 80 individual days. During the post-experimental period, soil compaction in control and test plots and along the forest trail increased and decreased in parallel suggesting a variable other than trampling alone was affecting the soil environment. While there was no visible change in plant cover of experimental plots, this cover was visibly disrupted along the trail.

Measures of nutrient supply rate in the rhizosphere before, during and after trampling disturbance were made using PRS ${ }^{\text {TM }}$ ion exchange probes. Pairs of anion and cation PRS ${ }^{\mathrm{TM}}$ probes were inserted in every plot at an angle so that the ion exchange membrane parts of the probes were within the zone where orchid roots might be found, 3 to $5 \mathrm{~cm}$ beneath the surface. In the case of experimental plots, PRS TM ion exchange probes were placed just outside the footprint during trampling and within the footprint during the post-trampling phase. Soil nutrient supply rates before trampling ranged from $12-29,0.8-6.1$, and $73-225 \mu \mathrm{g} \cdot\left(10 \mathrm{~cm}^{2}\right)^{-1} \cdot(10 \mathrm{~d})^{-1}$ for $\mathrm{NH}_{4}{ }^{+}-\mathrm{N}, \mathrm{P}$, and $\mathrm{K}$, respectively. During the trampling period, soil nutrient supply rates ranged from $5-23,1.8-7.8$, and $76-251 \mu \mathrm{g} \cdot\left(10 \mathrm{~cm}^{2}\right)^{-1} \cdot(10 \mathrm{~d})^{-1}$, and during the post- 


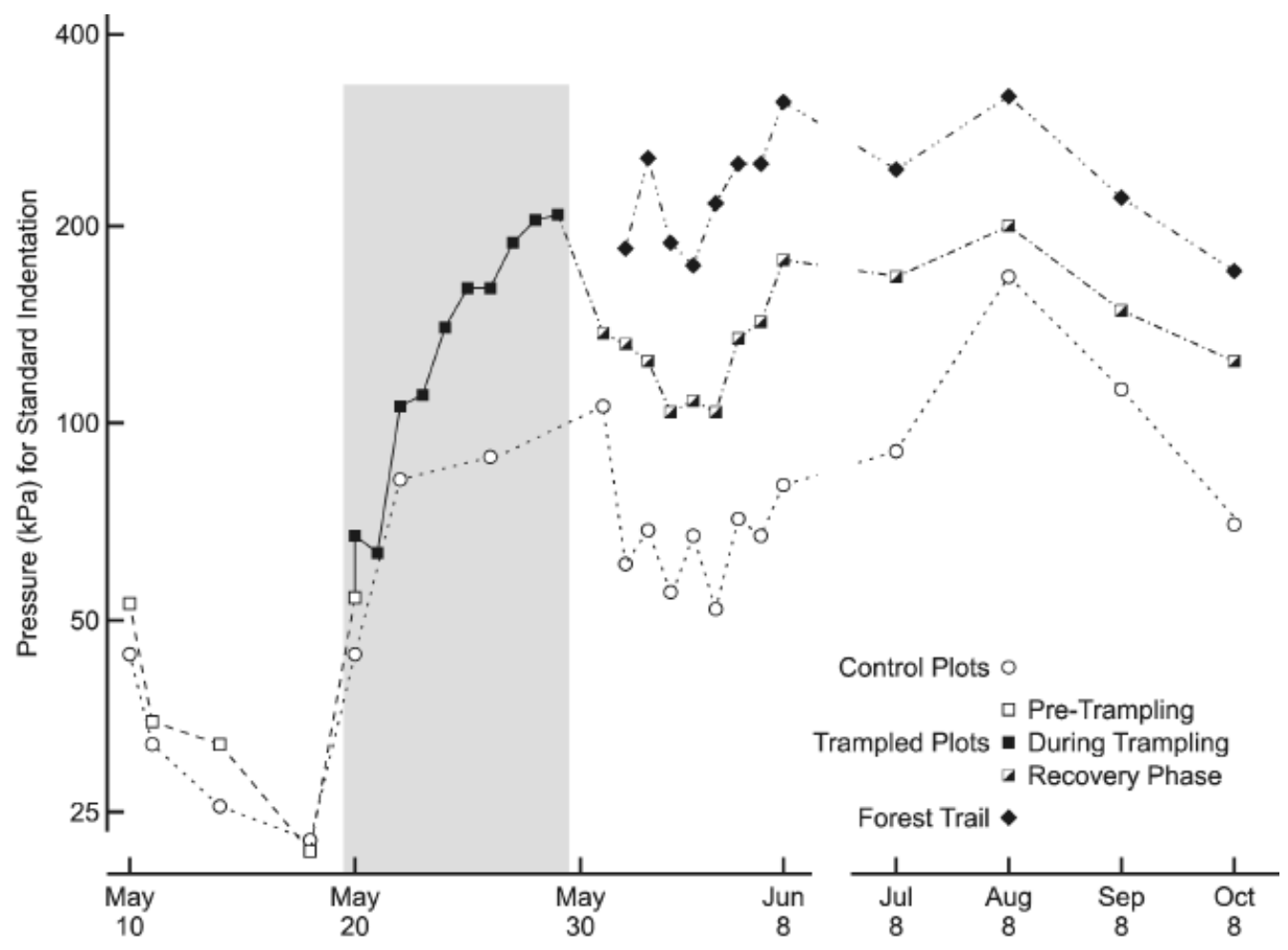

FIGURE 2. Changes in soil compaction, measured as pressure required to produce a standard indentation, before, during and after experimental trampling. The grey band indicates the trampling period: note that compaction was measured immediately before and just after the first trampling visit, and before trampling on the remaining days.

experimental period, rates ranged from 4-24, 1.1-7.9, and $65-131 \mu \mathrm{g} \cdot\left(10 \mathrm{~cm}^{2}\right)^{-1} \cdot(10 \mathrm{~d})^{-1}$ for $\mathrm{NH}_{4}{ }^{+}-\mathrm{N}, \mathrm{P}$, and $\mathrm{K}$, respectively. As there was much variation between control data and relatively small overall changes between controls and adjacent test plots, a more profound analysis of soil nutrient supply rates is necessary. This is beyond the scope of the present paper.

Nematode populations are best sampled in the autumn of North temperate regions when populations of free-living nematodes are at their maximum (Boag 1977). We removed two $5.5 \mathrm{~cm}$ dia cores to a depth of $3 \mathrm{~cm}$ from each plot and from the adjacent trail on September 8 ( 3 months after the experiment). In the test plots, we removed the cores from the sole and heel part of one randomly selected footprint. Samples were kept cool until active nematodes were extracted from $100 \mathrm{~cm}^{3}$ of soil at $22^{\circ} \mathrm{C}$ room temperature for $48 \mathrm{~h}$ using the Baermann Funnel technique (Thorne 1961). Nematodes were killed by gentle heating and examined microscopically for counting and determination of trophic group.

Numbers of nematodes extracted from control and test plots ranged from 17 to 290 per $100 \mathrm{~cm}^{3}$ soil. Based upon mouthparts and gut structure, we identified representatives of four feeding groups (trophic groups) of nematodes in most samples. Twenty-four different taxa were identified with the greatest diversity found in control plot 6 with 16 taxa. Bacterivorous/omnivorous nematodes were strongly predominant in trampled plots and along the forest trail. Fungivorous nematodes, which feed using a fine stylet to puncture fungal hyphae, were present in most samples but in much lower proportion in the test plots and along the forest trail (Table 1). Enrichment indicator nematode taxa (after Bongers 1990), including representatives of the Rhabditidae and Panagrolaimidae, were present in the trampled areas in greater proportion to basal microbiovores (Table 1). There were few herbivorous nematodes in most plots but somewhat 
TABLE 1. Mean \pm SEM proportions of nematode classes in the various sampling milieus.

\begin{tabular}{c|c|c}
\hline & $\mathrm{NCR}^{2}$ & $\begin{array}{c}\text { Enrichment/Total } \\
\text { Bacterivores }\end{array}$ \\
\hline Trampled Areas $^{\mathrm{b}}$ (15) & $0.91 \pm 0.02^{\mathrm{e}}$ & $0.72 \pm 0.06^{\mathrm{d}}$ \\
\hline Control Plots (5) & $0.60 \pm 0.12$ & $0.16 \pm 0.15$ \\
Undisturbed Areas (7) & $0.49 \pm 0.10$ & 0 (all) \\
All Controls (12) & $0.54 \pm 0.08^{\mathrm{e}}$ & $\mathrm{N} / \mathrm{A}$ \\
\hline
\end{tabular}

a Nematode Channel Ratio (Moore \& Hunt 1988) - Bacterivores (Bacterivores+Fungivores).

b Test Plots + Forest Trail: no differences in proportions between these milieus was discernable.

c Significantly greater than All Controls $(P<0.001)$

$\mathrm{d}$ Significantly greater than Control Plots $(P<0.001)$.

e No significant difference between Undisturbed Areas and Control Plots $(P>0.5)$.

more in forest trail soil samples. Predaceous nematodes (Mononchidae), were present in most samples but in small numbers. To test for any possible effect on the nematode analysis related to the insertion of PRSTM $^{\mathrm{TM}}$ probes, or on the presence/absence of orchids, we sampled soil cores taken from undisturbed sites outside of plot 1 at 10, 25 and $50 \mathrm{~cm}$ from Plant 1, and also from sites $5 \mathrm{~m}$ to the north, south, east and west of Plants 1, 7, 7, and 3 respectively where no orchids were growing. None of these samples from undisturbed soil contained active enrichment bacterivorous nematodes whereas soils from control plots $3 \mathrm{~A}, 6$, and 7 did have some which suggests that the insertion/removal of PRS $^{\mathrm{TM}}$ probes may have had a threshold disturbance effect (Table 1).

We have quantified the effect of 10 days (50 minutes total) of trampling on a terrestrial orchid rhizosphere and also of associated experimenter traffic along a forest trail. Soil became compacted and this effect was still discernable four months afterwards (Fig 2). The soil nematode community was noticeably affected by trampling with the appearance of active opportunistic enrichment bacterivorous nematodes (cp value of 1 according to Bongers 1990) and a decrease in fungivorous nematodes, an effect which was equally apparent along the more heavily compacted forest trail (Table 1). Populations of enrichment opportunists can increase rapidly in response to increased nutrient nitrogen availability but may not persist once the enrichment impulse has subsided (Bongers et al. 1995).
Enrichment indicator nematode taxa are opportunists associated with disturbed conditions (Bongers 1990, Bongers \& Ferris 1999, Yeates 2003). They have dormant larval stages which can become active after an appropriate stimulation. Their increase in numbers is considered to be in response to an increase in microbial activity associated with mechanical disruption of litter and increased availability of nutrient substrate (Bongers \& Ferris 1999). A preponderance of fungivores and low numbers of active enrichment bacterivorious nematodes would be expected in undisturbed forest (Bongers \& Ferris 1999, Neher 2001). "Hot spots" having larger than average numbers of fungivorous nematodes and of total nematodes can also be expected as reflecting the heterogeneity of the forest floor (Moore \& de Ruiter 1991). Enrichment opportunists might also appear after natural disturbance events including treefall or animal activity which can create an ephemeral nutrient supply. We could not discern a significant overall effect of trampling in terms of nutrient ion supply but given that there was no consistent decrease in the proportion of fungivorous nematodes in control plots as compared to undisturbed sites (Table 1 ), we conclude that the use of the PRSTM ion exchange probes was minimally disruptive to this trophic group. It is also possible that any change in nutrient ion supply resulting from our experiment might only become apparent at a later time. The concommitant decrease in fungivorous nematodes in test plots and along the forest trail suggests that their food source, fungal hyphae, has been depleted. This study shows that even small amounts of trampling can have a profound cryptic impact on the terrestrial orchid environment but what this means to the continuity of an orchid population remains to be elucidated.

\section{ACKNOWLEDGEMENTS}

The authors thank the National Capital Commission (Gatineau Park) for permission to conduct this study and Ryan Hangs, Western Ag Innovations Inc., for his helpful suggestions.

\section{LiteratuRe Cited}

Amacher, M.C. \& K.P. O’Neill. 2004. Assessing soil compaction on Forest Inventory \& Analysis phase 3 field plots using a pocket penetrometer. Research Paper RMRS-RP-46WWW. Fort Collins, CO: U.S. 
Department of Agriculture, Forest Service, Rocky Mountain Research Station. 7 p.

Boag, B. 1977. Factors influencing the occurrence and abundance of nematodes in forest soils in eastern Scotland. Ann. Appl. Biol. 86 : 446-450.

Bongers, T. 1990. The maturity index: an ecological measure of environmental disturbance based on nematode species composition. Oecologia $83: 14-19$.

Bongers, T. \& H. Ferris. 1999. Nematode community structure as a bioindicator in environmental monitoring. TREE $14: 224-228$.

Cole, D.N. 1995. Recreational trampling experiments: effects of trampler weight and shoe type. Research Note INT-RN425. Ogden UT: U.S. Department of Agriculture, Forest Service, Intermountain Research Station. 4 p.

Farrior, C. 2005. The effects of social trails on soil compaction and vegetative cover in forest and prairie ecotypes. PennScience $3:$ 30-34.

Hangs, R.D., K.J. Greer, C.A. Sulewski \& D. Hicks. 2002. Plant Root Simulator ${ }^{\mathrm{TM}}$-Probes: An effective alternative for routine soil testing. In Soils and Crops Workshop Proc., pp 120-130. Univ. Saskatchewan.

Hangs, R.D., K.J. Greer \& C.A. Sulewski. 2004. The effect of interspecific competition on conifer seedling growth and nitrogen availability measured using ionexchange membranes. Can. J. For. Res. 34 : 754-761.

Lajoie, P.G. 1962. Soil survey of Gatineau and Pontiac Counties, Québec. Queen's Printer, Ottawa, Canada. 94 p.

Light, M.H.S. 2004. Step softly: environmental stewardship. Native Orchid Conference J. 2 : 29-31.

Light, M.H.S., H. Koopowitz \& T.A. Marchant. 2003. The impact of climatic, edaphic and physiographic factors on the population behaviour of selected temperate and trop- ical orchids. In K. W. Dixon, S. P. Kell, R. I Barrett and P. J. Cribb (eds). Orchid conservation, pp. 159-182. Natural History Publications, Kota Kinabalu, Sabah.

Light, M.H.S. \& M. MacConaill. 2005. Long term studies - a case for orchid species survival. Selbyana 26 : 174-188.

Light, M. H. S. \& M. MacConaill. 2006. Appearance and disappearance of a weedy orchid, Epipactis helleborine. Folia Geobotanica 41 : 77-93.

Malmivaara-Lämäsa, M. \& H. Fritze. 2003. Effects of wear and above ground forest site type characteristics on the soil microbial community structure in an urban setting. Plant and Soil $256:$ 187-203.

Monz, C.A., T. Pokorny, J. Freilich, S. Kehoe \& D. AyersBaumeister. 2000. The consequences of trampling disturbance in two vegetation types at the Wyoming Nature Conservancy's Sweetwater River project area. USDA Forest Service Proc. RMRS-P-15. 15 : 153-159.

Moore, J.C. \& P.C. de Ruiter. 1991. Temporal and spatial heterogeneity of trophic interactions within belowground foodwebs. Agriculture, Ecosystems and Environment. 34 : 371-397.

Moore, J.C. \& H.W. Hunt. 1988. Resource compartmentation and the stability of real ecosystems. Nature 333 : 261-263.

Neher, D.A. 2001. Role of nematodes in soil health and their use as indicators. J. Nematol. $33: 161-168$.

Thorne, G. 1961. Principles of nematology. McGraw-Hill, New York.

Yeates, G.W., T. Bongers, R.G.M. de Goede, D.W. Freckman \& S.S. Georgieva. 1993. Feeding habits in soil nematode families and genera - an outline for soil ecologists. J. Nematol. $25: 315-331$.

Marilyn Light was educated in Agriculture and Microbiology at McGill University. She studies the long term behaviour of terrestrial orchid populations in Canada and was honoured by the North American Rock Garden Society in 2006 with the Edgar T. Wherry Award recognizing her outstanding contribution in the dissemination of botanical and horticultural information about native North American orchids. She chairs the North American Region and the Education Committees of the Orchid Specialist Group, SSC/IUCN.

Michael MacConaill obtained his education in Ireland and Canada. He is a retired professor of Pharmacology at the University of Ottawa, with interests in statistics and biomathematics. He serves as AOS Awards Photographer for several Canadian Orchid Societies and for the AOS judging center in Montréal. 